Department of Pathology, University Hospital, Tromsø M S Kearney

Department of

Ophthalmology, University Hospital, Tromsø

A Lyslo

L Dannevig

Department of Zoology, Tromse

Museum

A C Nilssen

Department of Ophthalmology, Rikshospitalet, Oslo P Syrdalen

Correspondence to: Dr M S Kearney, Department of Pathology, 9012 Regionsykehuset Tromsø, Norway

Accepted for publication 23 October 1990

Figure 1

Ophthalmomyiasis interna posterior caused by reindeer warble fly larva. (A) Living larva in the vitreous; ( $B$ ) hypopigmented linear subretinal track.

\title{
Ophthalmomyiasis caused by the reindeer warble
} fly larva

\author{
M S Kearney, A C Nilssen, A Lyslo, P Syrdalen, L Dannevig
}

\begin{abstract}
Two boys with ophthalmomyiasis caused by the first instar larva of the reindeer warble fly Hypoderma tarandi are reported. Both were 9 years old and came from the coast of northern Norway. One had ophthalmomyiasis interna posterior and one eye had been removed because of progressive pain and blindness. Histological examination showed the remains of a fly larva. The second boy had ophthalmomyiasis externa with a tumour in the upper eyelid, and histological examination showed a warble with a well preserved larva. Identification of the parasite in the histological material was based on the finding of cuticular spines and parts of the cephalopharyngeal skeleton identical with those of the first instar larva of $H$ tarandi.
\end{abstract}

Ophthalmomyiasis denotes invasion of the eye or its coverings by larvae of the Diptera which cause myiasis, ${ }^{1}$ including the reindeer warble fly Hypoderma tarandi, first seen in a boy from northern Norway in $1980 .^{2}$ Other reported cases have occurred in residents or visitors to northern Scandinavia. ${ }^{3-5}$

Ophthalmomyiasis is usually diagnosed by clinical examination. In ophthalmomyiasis externa larvae are found in the conjunctival sac, or rarely, in a warble on the eyelid. Ophthalmomyiasis interna is diagnosed by finding a larva in the anterior or posterior segments, or by its characteristic linear tracks beneath the retina (fig 1 ).

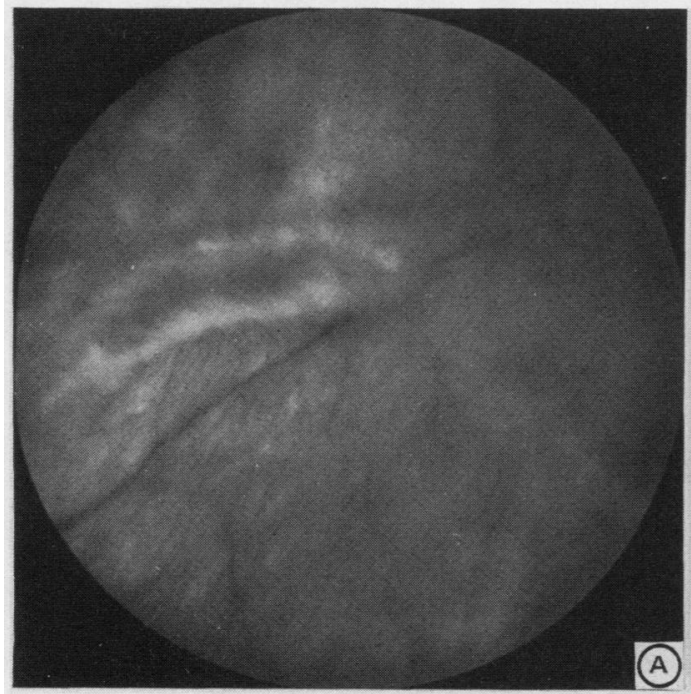

In many cases the intact larva has been surgically removed and its species determined by its external morphology. We present here two cases of ophthalmomyiasis caused by the first instar larva of Hypoderma tarandi, in which the parasite was found and identified by histological examination.

\section{Case reports}

CASE 1

A nine year old boy from the coast of northern Norway presented early in October 1983 with right-sided conjunctivitis after a jellyfish had been thrown in his face. Generalised uveitis developed and the left eye also became swollen. There was peripheral eosinophilia $\left(860 \times 10^{6} / 1\right)$ and a biopsy specimen of the left upper eyelid showed eosinophilic infiltration. Serological tests for toxoplasmosis and toxocariasis were negative. Several courses of steroids and an anthelmintic, diethylcarbamazine, were given. In January 1984 a rightsided retinal detachment was operated on and a vitrectomy performed. In September 1984 the right eye was enucleated because of increasing pain and blindness. The remains of a fly larva were found on histological examination.

\section{CASE 2}

A nine year old boy from the same area presented in mid-August 1986 with episodes of pain and swelling of the right upper eyelid. A pea-sized tumour was excised from the lateral angle of the eye, and histological examination showed a warble with a well preserved fly larva.

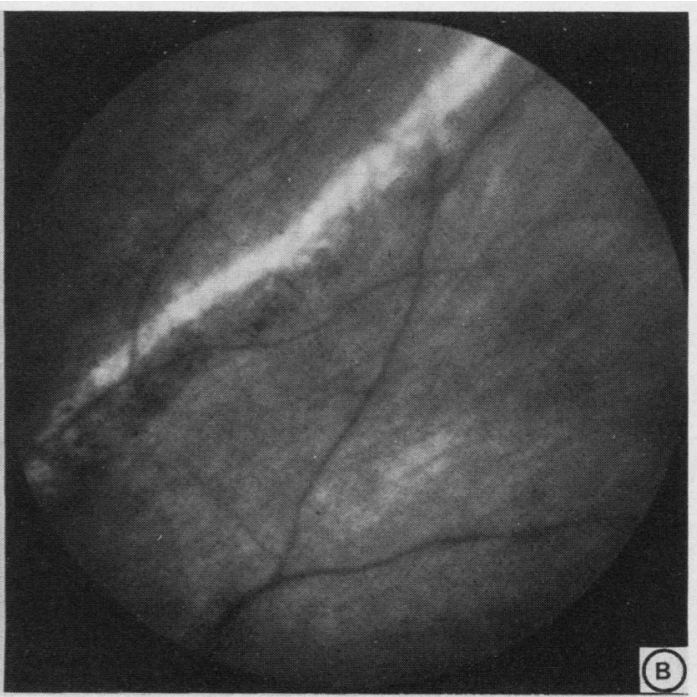




\begin{abstract}
Methods
All tissue samples were fixed in formalin and embedded in paraffin wax.
\end{abstract}

CASE 1

A skin biopsy specimen was taken from the left upper eyelid measuring $7 \times 4 \times 1 \mathrm{~mm}$; serial sections were cut. Serial sections were cut of the right eye and 61 of these contained parts of a parasite. A three-dimensional model of the parasite was made using a Leitz tracing device.

CASE 2

The excised swelling from the right upper eyelid consisted of two pieces of tissue measuring $8 \times 7 \times 4 \mathrm{~mm}$ and $4 \times 4 \times 3 \mathrm{~mm}$. These were sectioned serially and 29 sections contained part of a parasite.

\section{Reference larvae}

First instar larvae of the reindeer warble fly
Hypoderma tarandi and the reindeer throat botfly Cephenemyia trompe were collected from freshly slaughtered reindeer and fixed in $70 \%$ ethanol. First instar larvae of the moose throat botfly Cephenemyia ulrichii were collected from a moose killed in the Pasvik area of eastern Finnmark, near the Russian border. The larvae were studied after clearing in $10 \%$ potassium hydroxide, or in a few cases, by using conventional histological techniques.

One of us (MSK) studied the larvae of the more important Diptera which cause myiasis in the reference collections of the Department of Entomology, the Natural History Museum, London, and the Department of Medical Parasitology, London School of Hygiene and Tropical Medicine. Particular attention was paid to the morphology of the cuticular spines of the following larvae: Hypoderma bovis and $H$ lineatum, Dermatobia hominis, Gasterophilus intestinalis, Oestrus ovis, Cordylobia anthropophaga, Cochliomyia hominivorax, and Chrysomya bezziana.
Figure 2 Case $1(A)$ Vitreous with fibroinflammatory mass and an abscess containing the parasite (arrow). Note the iris bombe; (B) remains of the parasite. The resemblance to a reindeer is coincidental.

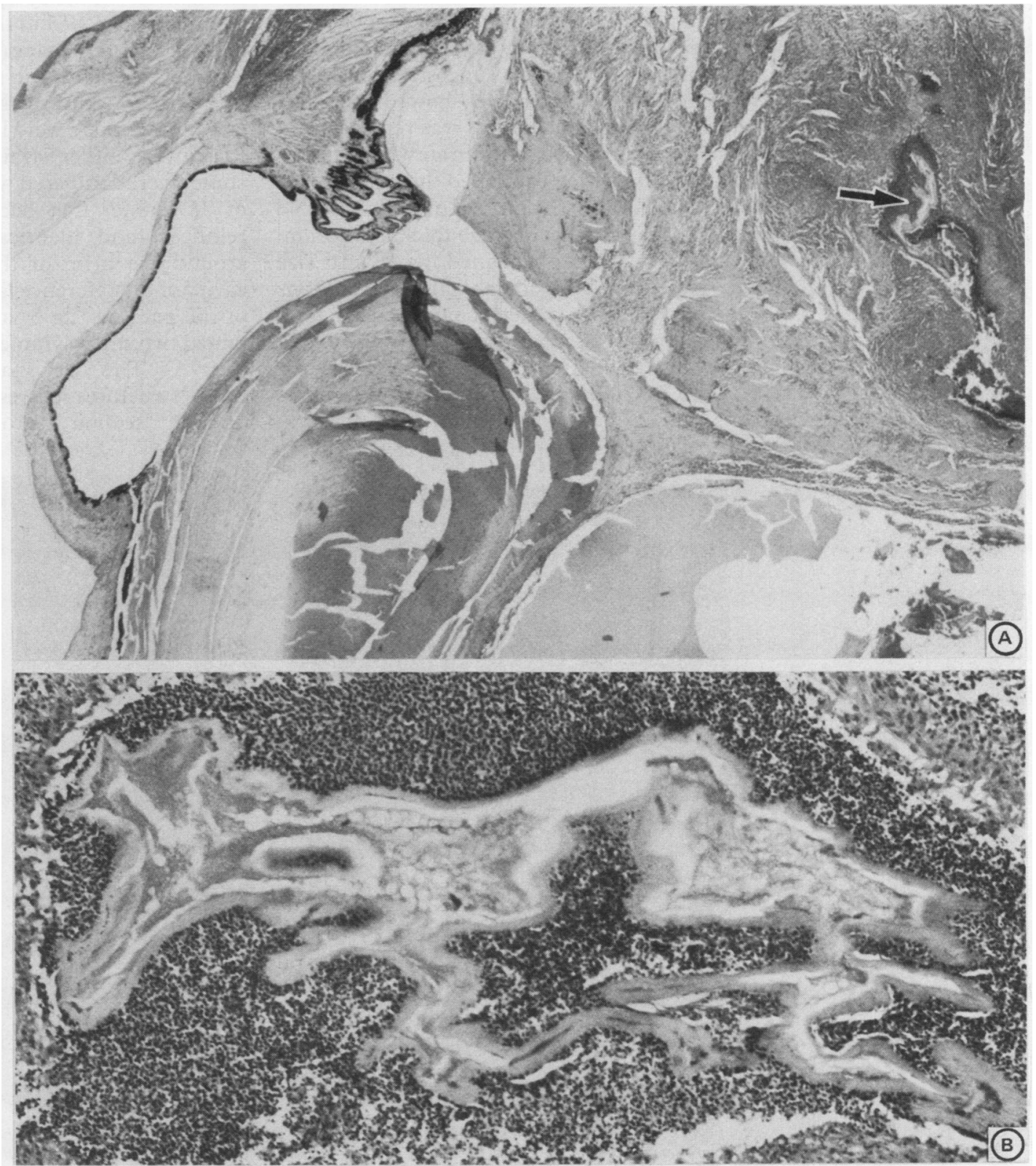


Figure 3

Case 1 Outline of parasite in serial sections. Distance between sections 70 and 120 is about $0.3 \mathrm{~mm}$. $x$ indicates anterior end.

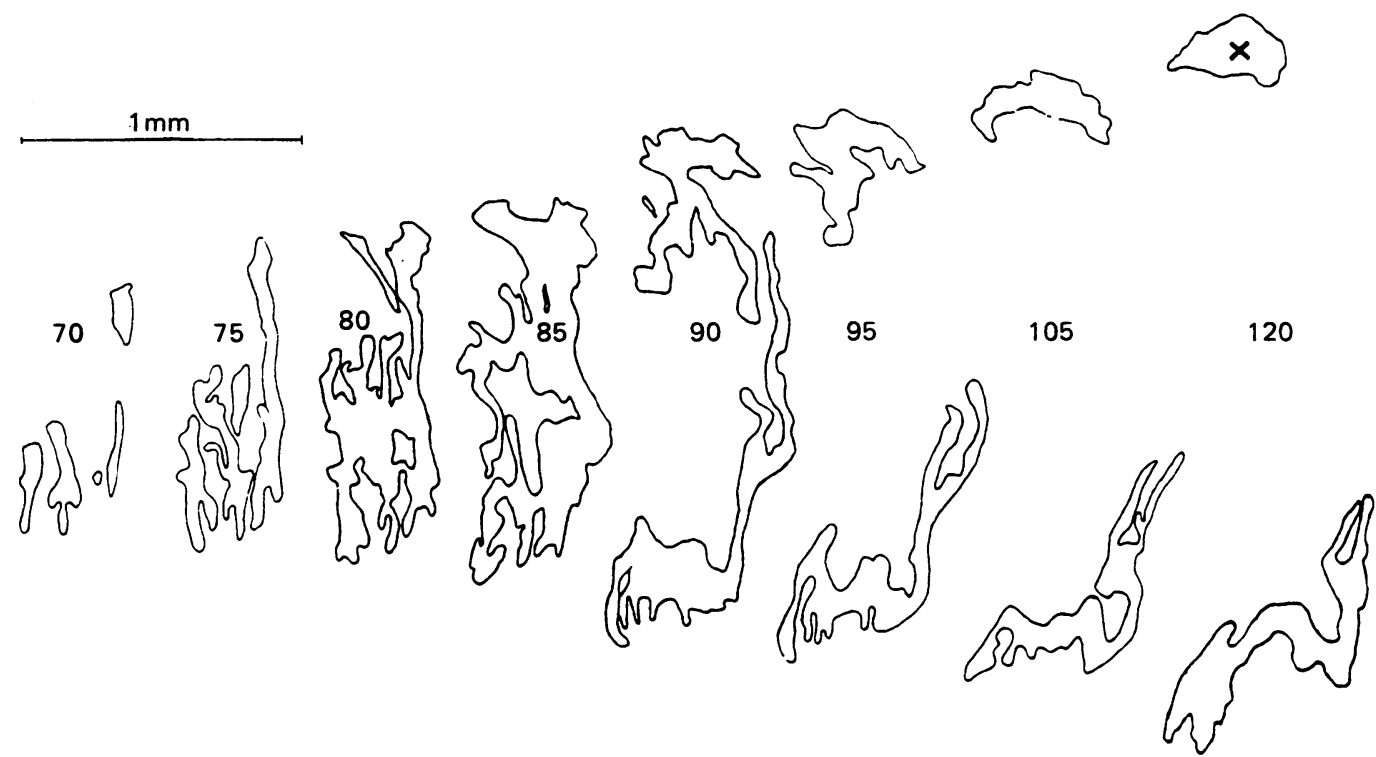

Results

CASE 1

The biopsy specimen from the left upper eyelid was heavily infiltrated by eosinophils. No parts of a parasite, or necrosis suggestive of a track, were seen. The right eye showed complete phthisis bulbi. The vitreous was replaced by a fibrosing granulomatous infiltrate with an eosinophil abscess which contained the remains of a long dead parasite, length $2.5 \mathrm{~mm}$ (fig $2 \mathrm{~A}$ ). No details of the cuticle, average thickness $15 \mu \mathrm{m}$, or internal structure remained (fig $2 B$ ). Its size and shape varied considerably in serial sections (fig 3), and a three dimensional reconstruction of the parasite was made (fig 4). This resulted in an elongated flattened structure measuring $2.5 \times 0.7 \times 0.3 \mathrm{~mm}$, with a slight curve, and a constriction or twist at one end. The observa-

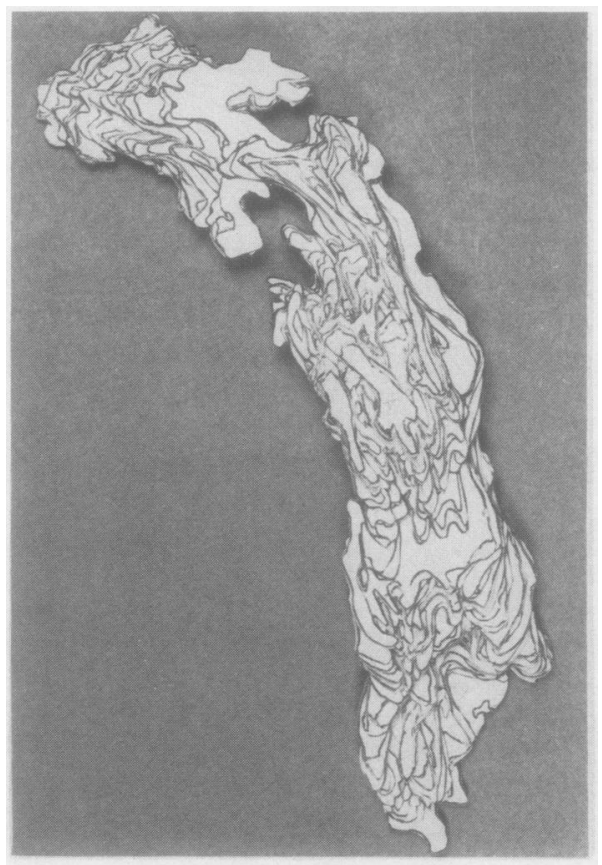

Figure 4 Case 1 Reconstruction of parasite from serial sections. tion of a yellow-brown sclerotised hook, $11 \mu \mathrm{m}$ in diameter, in the cytoplasm of a foreign body giant cell (fig 5 ) led to the finding of nine more spines of varying shape (fig 6). Most had a broad circular baseplate with a diameter greater than twice the width of the spine. Some were short and blunt, others were longer and pointed, and these were either straight or hook-like. The spines were compared with the first instar larva of $H$ tarandi that had been collected from reindeer, and identical spines were found around the brim of the posterior spiracular cavity of the reference larvae (fig 7). At one end of the parasite (fig 3) a hollow structure contained two small symmetrical sclerotised plates (fig 9A). The size, shape, and orientation of these structures corresponded well with an oblique section through the pharyngeal

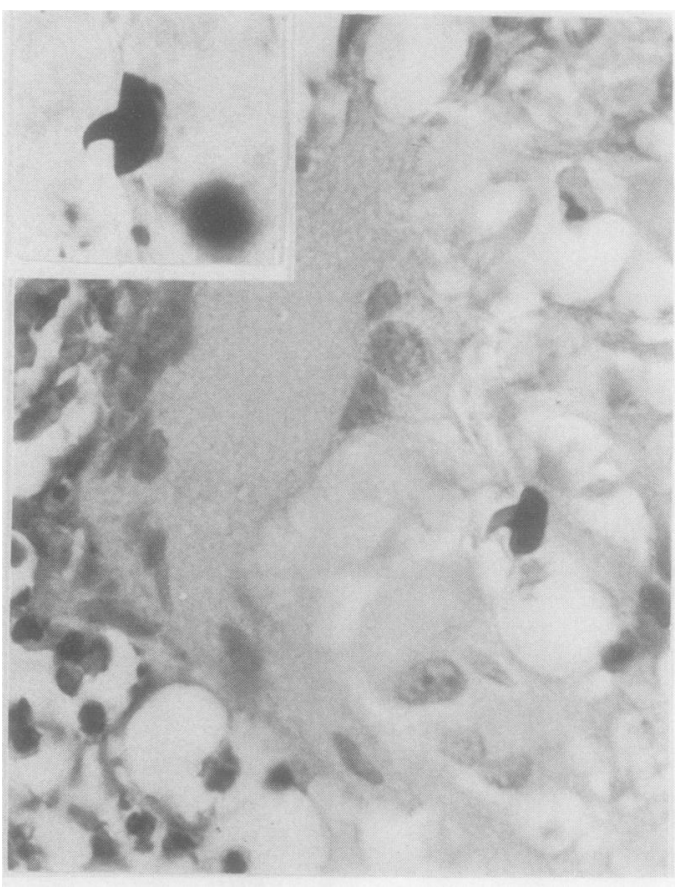
Inset shows similar hook from first instar larva of $H$ tarandi.
Figure 5 Case 1 Foreign body giant cell with hook. 
Figure 6 Case 1 Hooks and spines of varying shape in foreign body giant cells.
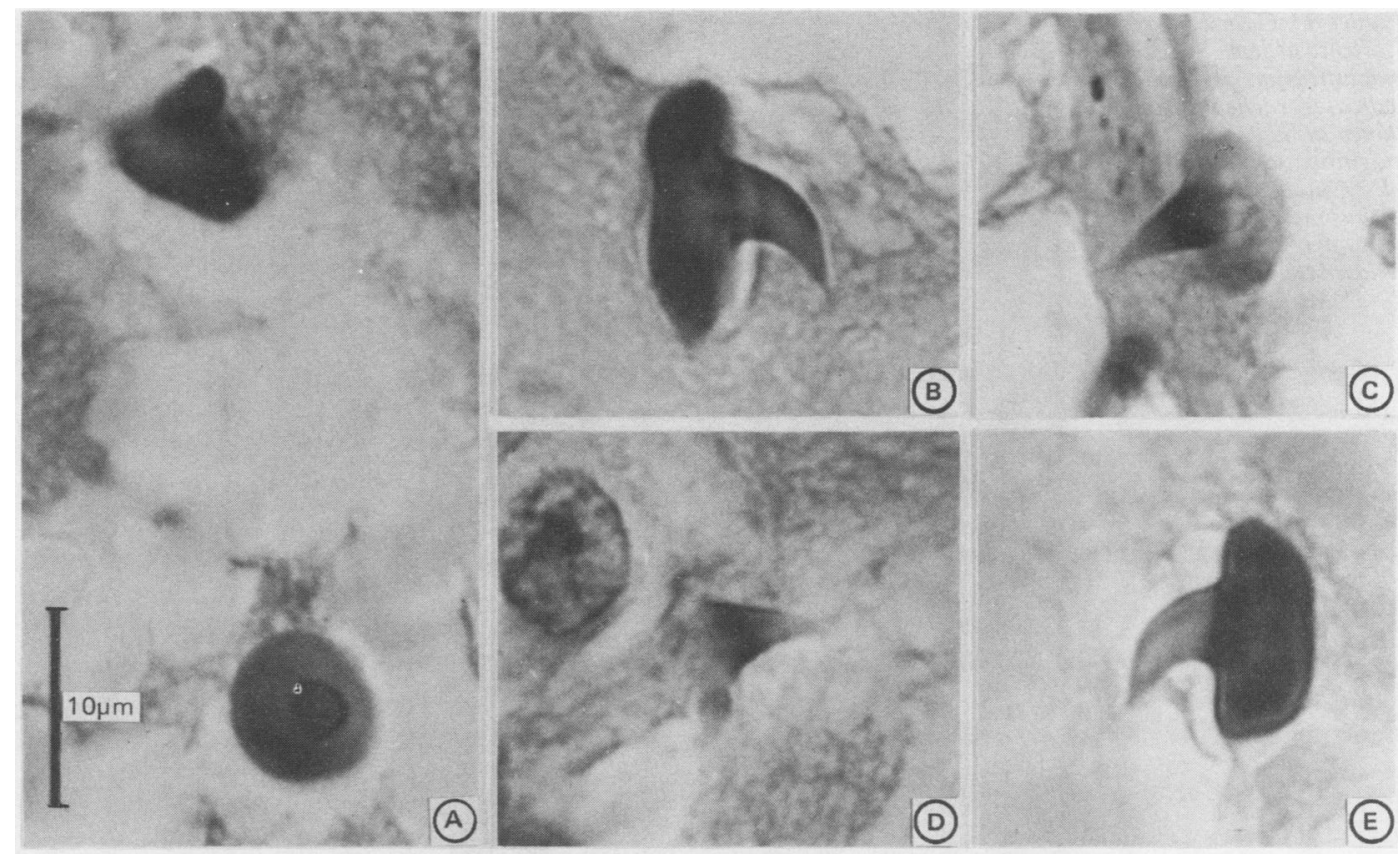

sclerites of the first instar larva of $H$ tarandi (fig 9B). There was no sign of a track or eosinophilic infiltration of the optic nerve, suggesting that the larva had penetrated the globe elsewhere.

\section{CASE 2}

The tissues of the eyelid were heavily infiltrated with eosinophils, lymphocytes, and poorly defined epithelioid granulomas. A track-like cavity contained abundant granular eosinophilic material which surrounded a well preserved cylindrical parasite measuring $2.35 \times 0.83 \mathrm{~mm}$, which appeared viable at the time of fixation (fig 8A). This was identified as an insect larva by a respiratory system consisting of branching tracheae with spiral thickenings (fig 8A) ${ }^{67} \mathrm{~A} 7 \mu \mathrm{m}$ thick cuticle with spines and a layer of hypodermal cells, slender fascicles of cross-striated muscle (fig $8 \mathrm{~B}$ ), and a dilated gut (fig 8A) were also seen. The pharynx with its paired sclerites (fig 9C) was found at one end of the larva, and these structures corresponded well with those of reference specimens of the first instar larva of $H$ tarandi (fig 9B).

Hook-shaped spines with a cireular base were also found on the caudal segment of reference first instar larvae of the cattle warble flies Hypoderma bovis and $H$ lineatum, and these were identical with those found in case 1 and the first instar larva of $H$ tarandi. Similar shaped hooks were also seen on the anterior part of the second instar larva of the human botfly Dermatobia hominis, but these were much larger, $18-180 \mu \mathrm{m}$ diameter, and were more heavily sclerotised.
Figure 7 Brim of posterior spiracular cavity of first instar larva of $H$ tarandi from a reindeer, with hooks and spines indentical with those from case 1.

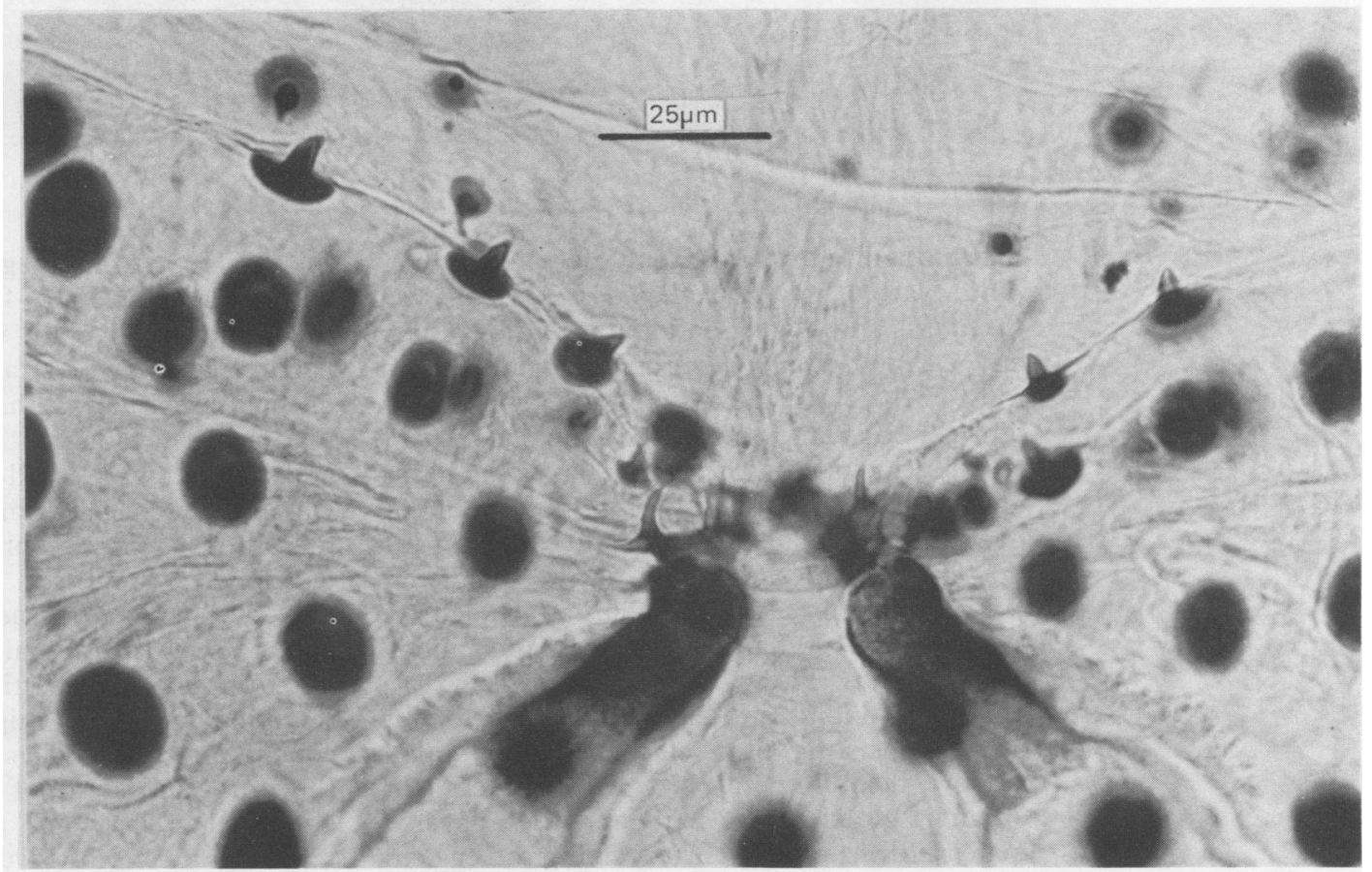


Figure 8 Case $2(A)$ Parasite at low magnification. Arrow indicates tracheal system shown at higher magnification in the inse (B) Cuticle of parasite with spines, hypodermal cells (arrow) and crossstriated muscle.

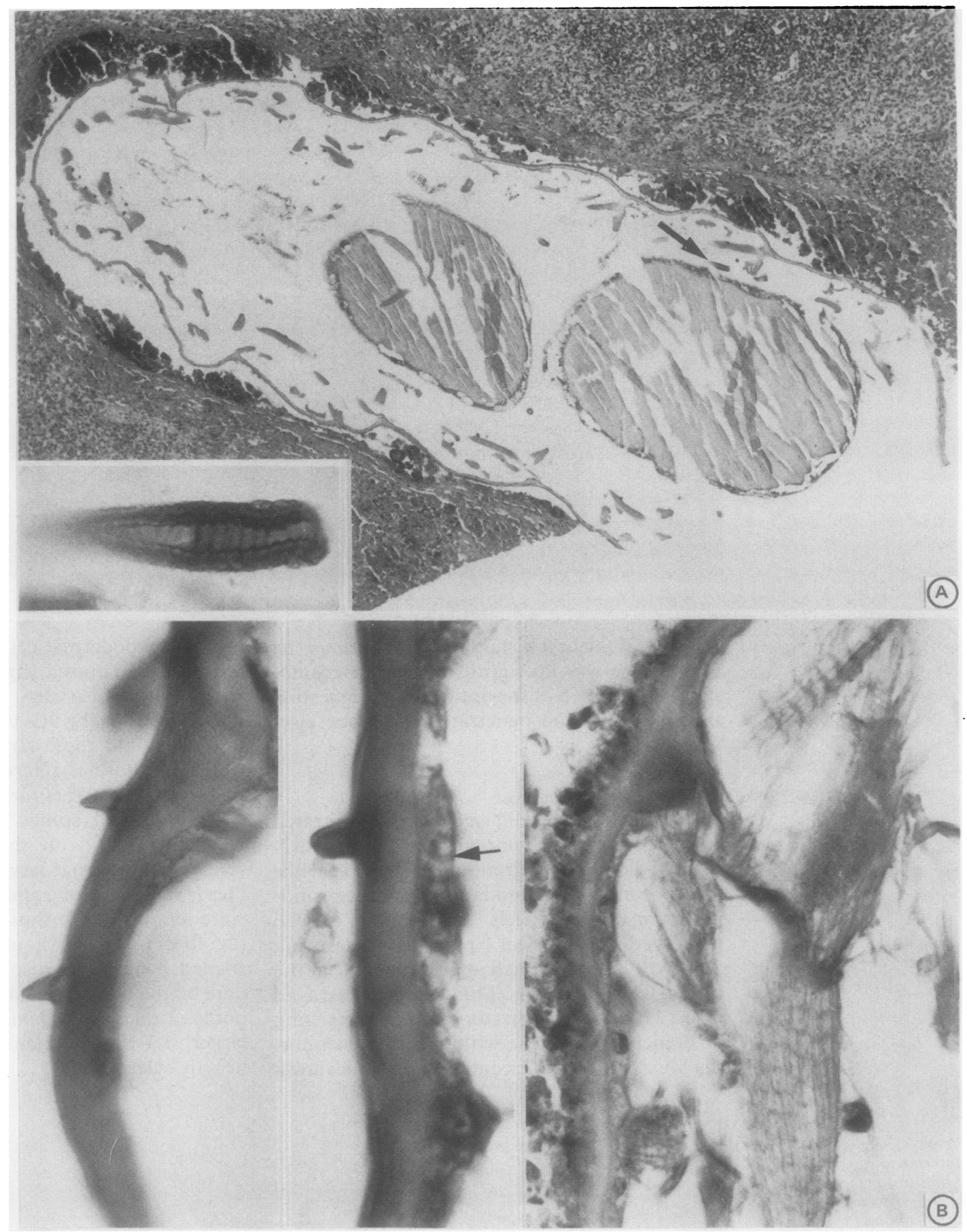

The parasite and its life cycle

The warble fly Hypoderma (Oedemagena) tarandi is an obligate endoparasite of reindeer and caribou Rangifer tarandus, occurring in most of the Holarctic distribution of the host. ${ }^{8}$ The generic name used here follows the recent revision including Oedemagena as a subgenus of Hypoderma. ${ }^{9}$ Adult flies resemble bumblebees; they do not feed, bite, or sting, and live for up to a month. Egg-laying occurs mainly in July and August. Adult females attach eggs to the leg and body hairs of reindeer, and can lay 500-700 eggs. These are cigar-shaped (fig 10), about $1 \mathrm{~mm}$ long, and have a basal attachment organ consisting of a clasper region and a narrow flexible petiole. ${ }^{1011}$ The attachment organ is glued to the hair, and the adhesive material dries rapidly, firmly fixing the eggs to the hair. Two to eight eggs are attached to hairs with a diameter of $16-42 \mu \mathrm{m}$, which is mainly the reindeers' woolly undercoat or summer hair. ${ }^{12}$ Eggs may be attached to more than one of the thinner hairs. The larvae (fig 10B) hatch in four to seven days, ${ }^{12}{ }^{13}$ are $0 \cdot 7-0.8 \mathrm{~mm}$ long, ${ }^{8}$ and covered with small denticles (figs $7,10 \mathrm{~B}$ ) which reduce backward movement during migration. The cephaloskeleton is well developed ${ }^{10}$ (fig 9B).

Newly hatched larvae penetrate the skin in about six hours, ${ }^{14}$ mainly by means of the lipolytic and proteolytic action of their oral secretions. ${ }^{1516}$ They migrate in the subcutaneous connective tissues and muscles towards the rump and spine of the host. ${ }^{1718}$ The first larval stage lasts for about three months, ${ }^{8}$ reaching a length of up to $9 \mathrm{~mm}$. Warbles 
Figure 9 Anterior end of parasite with

cephalopharyngeal

skeleton. Arrows indicate pharyngeal sclerites. $(A)$ Case 1; (B) first instar larva of $H$ tarandi from $a$ reindeer (cleared unstained preparation); (C) Case 2.
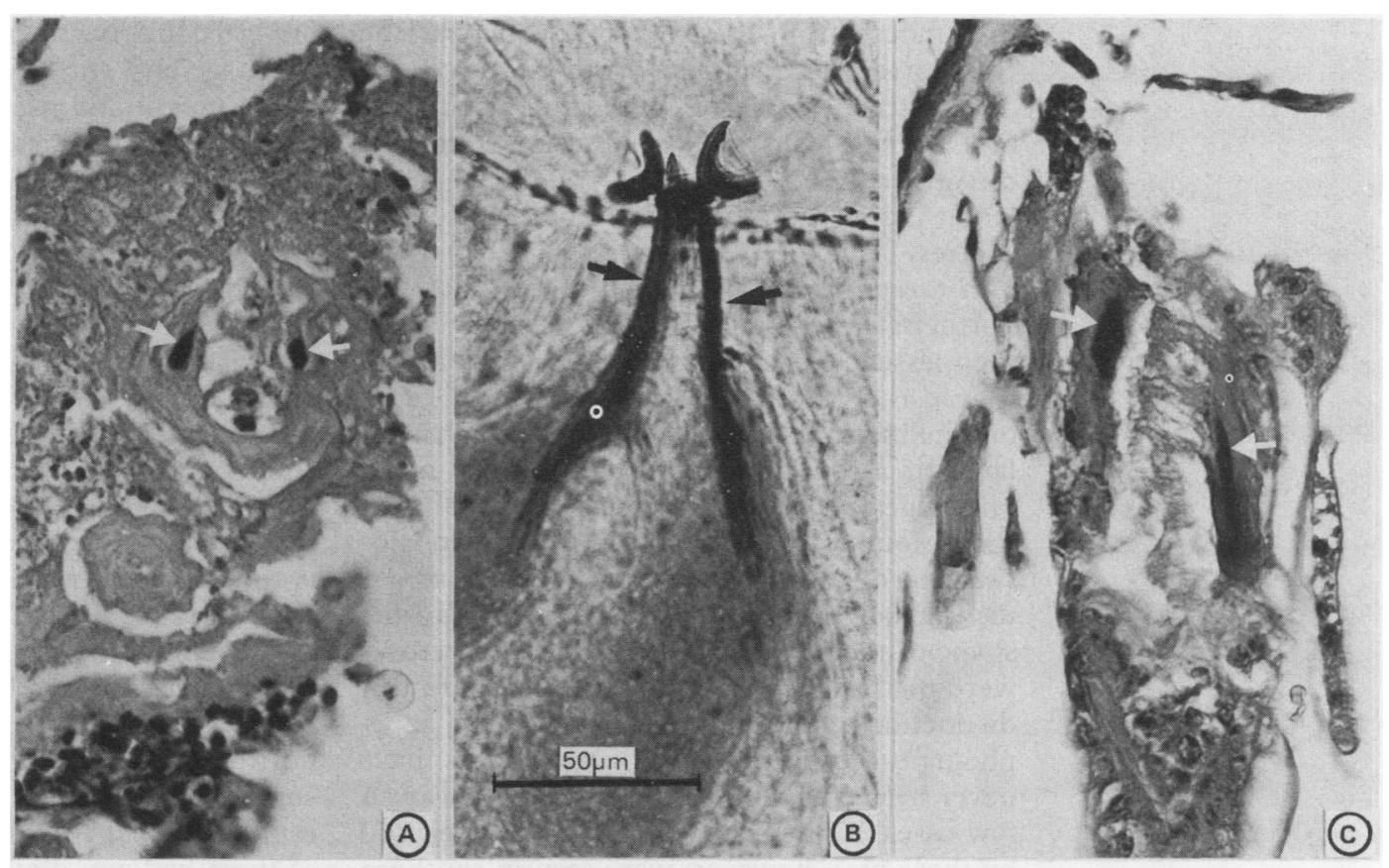

appear when the first instars moult, beginning in October. They are mostly found in the posterior region of the back where the larvae cut breathing holes through the skin. ${ }^{810} 19$ The second and third (final) instars last three to four months each and the mature larvae leave the host, usually in May. The larvae fall to the ground, pupate, and hatch 21-33 days later, depending on the temperature.

\section{Discussion}

Identification of a parasite in histological sections can be difficult, particularly if it has been dead for some time, as in case 1. Although there was a clinical suspicion that this might have been a reindeer warble fly larva, we were intrigued by the apparent association with the jellyfish, and wondered if the parasite could be a marine organism, or an intestinal parasite from bird faeces which might have contaminated the jellyfish. The finding of parts of the cephaloskeleton and characteristic spines, however, identified the parasite as an insect larva. A tracheal system in the parasite from case 2 readily identified it as an insect larva. ${ }^{67}$
The determination of the species of a fly larva usually requires an intact specimen so that the cephalopharyngeal skeleton and posterior spiracles can be studied. Species determination from histological sections is much more difficult. This was achieved in our cases by a detailed study of serial sections of the parasites, identifying the mouthparts and distinctive cuticular spines, which were then compared directly with the first instar larva of the flies which cause myiasis and are known to occur in our special geographical region.

Two species of Diptera, which cause myiasis, are common in northern Norway; these are the reindeer warble fly Hypoderma tarandi and the reindeer throat botfly Cephenemyia trompe. Both are obligate parasites. $C$ trompe does not cause ophthalmomyiasis in man, but can cause keratitis in reindeer..$^{20} \mathrm{~A}$ similar parasite, the moose throat botfly Cephenemyia ulrichii, caused ophthalmomyiasis externa in a 66 year old man and a 35 year old woman from Finland. ${ }^{21}$ Although the moose Alces alces is common in northern Norway, the moose throat botfly $C$ ulrichii has not been previously reported in Norway. It was found recently, however,
Figure 10 Eggs of $H$ tarandi $(A)$ attached to end of a reindeer hair. arrow indicates petiole of attachment organ; $(B)$ cleared preparation showing first instar larva inside egg, anterior end to right.
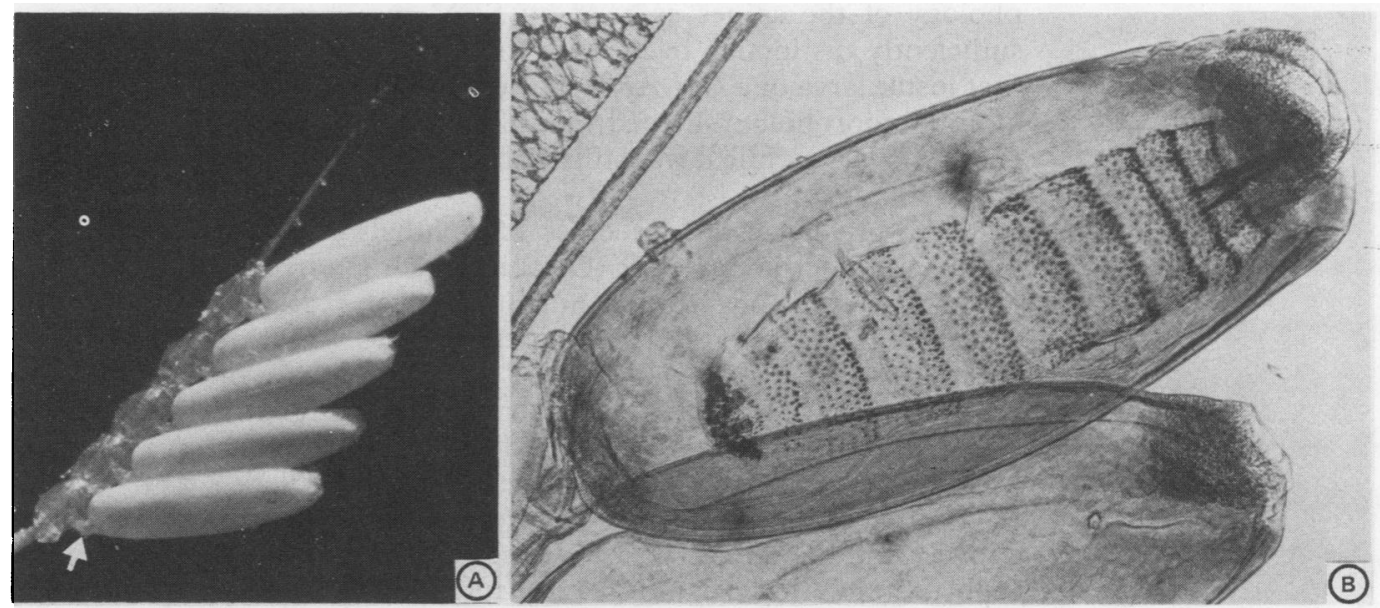
in a moose from the Pasvik region near the Russian border ${ }^{22}$ and in northern Sweden. ${ }^{23}$ The pharyngeal sclerites of the first instar larva of $C$ trompe and $C$ ulrichii were compared directly with those of our cases, and were much larger structures, thus excluding these two species.

$H$ tarandi is closely related to the greater or northern cattle warble fly Hypoderma bovis, and the lesser or common cattle warble fly Hypoderma lineatum, both of which cause ophthalmomyiasis in man. ${ }^{24-27}$ The first instar larva of $H$ lineatum could be excluded as its pharyngeal sclerites are much broader ${ }^{8}$ than those found in our patients. The cephaloskeleton of the first instar larva of $H$ bovis is distinguished from that of $H$ tarandi by the shape of the labial sclerites. ${ }^{8}$ These structures were missing in our cases, and therefore this distinction could not be made using morphological criteria. Cattle warble flies have never been found in northernmost Norway. A few cases of human cutaneous myiasis caused by these flies, however, were seen in southern Norway many years ago, ${ }^{28}$ last being reported in $1932 .{ }^{29}$ The cattle warble flies $H$ bovis and $H$ lineatum have now disappeared from the whole country, the last known observation having been made in 1947. We concluded, therefore, that the parasite in our patients was the first instar larva of Hypoderma tarandi. The sheep nasal botfly Oestrus ovis, which is the commonest cause of ophthalmomyiasis externa, is not known to occur in Norway.

The distinctive hooks that were found in case 1 are not specific for $\mathrm{H}$ tarandi ${ }^{19}$ We found, like others, identical hooks on the first instar larva of the cattle warble flies $H$ bovis and $H$ lineatum..$^{25} 3031$ They are also seen on the first instar larva of the rodent grub fly Oestromyia leporina Pall (Hypodermatidae). ${ }^{32}$ Similar shaped but larger hooks $(18-180 \mu \mathrm{m})$ were found on the anterior part of the second instar larva of the neotropical cuterebrid Dermatobia hominis. ${ }^{1}$ Most of the spines of this larva are so large as to be easily visible with the naked eye, and together with its distribution (Central and South America), make confusion with this parasite unlikely. Others have used scanning electron microscopy (SEM) to identify an incomplete Cuterebra larva removed from an eye. $^{33}$ The cephalopharyngeal skeleton and posterior spiracles were missing, but the morphology of the spines as seen by SEM was sufficiently distinctive to identify the larva as first instar larva of a Cuterebra species. Details of spine morphology helped identify another Cuterebra larva while it was still attached to the posterior cornea. ${ }^{34}$

There are five previous cases of ophthalmomyiasis interna posterior (OIP) in which a larva was found on gross examination of an enucleated eye. These were identified as Hypoderma bovis, ${ }^{35}$ Hypoderma ?bovis, ${ }^{36}$ undetermined, ${ }^{37} \mathrm{H}$ bovis ${ }^{38}$ and Oestridae. ${ }^{39} \mathrm{We}$ found four cases of OIP diagnosed by histological examination. The larvae were identified as Diptera, probably $\mathrm{H}$ bovis, ${ }^{40}$ Diptera, ${ }^{41}$ Oestridae, ${ }^{42}$ and Diptera, probably $H$ bovis. ${ }^{43}$ Two reports from Amsterdam in $1926^{41}$ and $1934^{43}$ are particularly interesting. Both were boys, aged six and three years, with diagnoses of tuberculosis, and pseudoglioma or glioma. In each case histological examination showed a well preserved fly larva with the same distinctive hook-like cuticular spines that we found in case 1. The larva in Zeeman's patient ${ }^{41}$ can be retrospectively identified as Hypoderma, probably $H$ bovis. There are two other reports in which myiasis was diagnosed by histological examination, these were a pulmonary coin lesion containing a horse bot Gasterophilus ${ }^{44}$ and two cases of enteric myiasis caused by Sarcophaga and Phormia larvae. ${ }^{45}$ Useful information on the histological diagnosis of myiasis is given in a review of North American cuterebrid myiasis. $^{7}$

We do not know how our two patients were infested with the reindeer warble fly larva. They both came from the coast of Finnmark, the northernmost county of Norway, where the summer pastures of the semi-domesticated reindeer Rangifer tarandus are found. Neither of them had any direct contact with reindeer, but the adult insect has a flying range of several miles and has occasionally been found indoors on the Finnmark coast. It was suggested that the fly might deposit eggs on the hair of the eyebrows or eyelids, ${ }^{8}$ but in man eggs of $H$ tarandi are usually found on the hair of the scalp. ${ }^{1028}$ Female $H$ tarandi often settle on the top of the head (Nilssen AC, unpublished observation), probably because the fly needs a certain amount of hair as a stimulus to settling. The onset of symptoms in late summer or early autumn is characteristic and is clearly related to the time of egg laying and hatching of the larva.

Interestingly, ophthalmomyiasis caused by $H$ tarandi has not been reported in the Sami reindeer herders, nor do they have an increased incidence of eye problems compared with the rest of the population. $H$ tarandi is usually regarded as monospecific but larvae have been recovered from man, musk ox Ovibus moschatus, ${ }^{46} 47$ roe deer Capreolus capreolus, ${ }^{48}$ red deer Cervus elaphus, ${ }^{49}$ and probably from moose Alces alces. ${ }^{49}$

Other cases of human myiasis caused by $H$ tarandi have recently been reported from Norway and Sweden, ${ }^{3-5}$ and together with our cases, nine patients infested with the first instar larva of $H$ tarandi have now been reported. There are seven with OIP, one with ophthalmomyiasis externa, and one with cutaneous myiasis. Six of the seven patients with OIP were operated on, and in five the larva was extracted. In one case a successful emergency vitrectomy and retinotomy were done to remove a subretinal $H$ tarandi larva as it moved towards the fovea centralis, threatening irreversible damage to central vision. ${ }^{5}$ In two cases the eye went blind, including our case 1 , in which the eye was enucleated. In the seventh case of OIP the larva was left in situ and its identity is unconfirmed. ${ }^{350}$

The larva enters the eye by penetrating the sclera. ${ }^{40-42}$ It can wander in the subretinal space, leaving a hypopigmented track behind it. ${ }^{51}$ After perforating the retina the larva may be trapped in the vitreous cavity. It can move 
between posterior and anterior segments of the eye $\mathrm{e}^{52}$ and dislocation of the lens is common. Iridocyclitis, uveitis, and retinal haemorrhage and detachment may follow. Earlier cases of OIP were often diagnosed as tuberculosis or malignant neoplasm. Occasionally an intraocular larva may die without exciting an inflammatory response and remain in situ with preservation of vision for up to 38 years. ${ }^{350}$

OIP is a rare disease; we found only 54 well documented cases. 2242527335354 In 30 cases a larva was recovered, either by extraction of the larva, ${ }^{2-52527335255-62}$ or after enucleation of the eye. ${ }^{35-4363}$ In 18 cases a larva was seen but not recovered, being either left in situ, ${ }^{3245064-70}$ not found after vitrectomy. ${ }^{2671}$ or destroyed by photocoagulation. ${ }^{72-75}$ Subretinal tracks without a larva were seen in six cases. ${ }^{5076-78}$ The 30 recovered larvae were $H$ bovis ( $\mathrm{n}=$ 12), ${ }^{25} 353638405561-63$ Hypoderma tarandi ( $\mathrm{n}=$ 6), ${ }^{2-5} H$ lineatum $(n=2),{ }^{5759}$ Hypoderma unspecified $(\mathrm{n}=1),{ }^{27}$ Diptera $(\mathrm{n}=1),{ }^{41}$ Oestridae $(\mathrm{n}=2),{ }^{39} 42$ Cuterebra $(n=2),{ }^{3352}$ Rhinoestrus purpureus $(n=1),{ }^{56}$ Oestrus ovis $(n=1),{ }^{58}$ and unidentified $(\mathrm{n}=2) .{ }^{3760}$

Hypoderma tarandi now seems to be the commonest cause of OIP in Europe. Its relatively recent debut as a human parasite may be associated with the large increase in the reindeer population in northern Norway in recent years. ${ }^{7980}$ In April 1988 there were about 190000 reindeer in Finnmark, ${ }^{79}$ and almost all of them are infested with $H$ tarandi, with a range of $0-640$ larvae per reindeer ${ }^{81}$ There is no systematic programme for the eradication of the parasite in Norway, although some treatment with Ivermectin is in progress. ${ }^{82}$ Northern Scandinavia is a popular tourist area, especially in the summer when the infective female flies are active. Further cases may be expected.

First presented at the 154th Meeting of the Pathological Society at Oxford, 7-9 January 1987. Published as an abstract in J Pathol 1987;151:89.

Dr S Lindal, Department of Pathology, University Hospital Tromse, found the parasite in the biopsy specimen from case 2 and kindly referred the material to MSK. We are grateful to Merete Lorentzen, R E Haugerud, Dr W N Beesley, O Helle, Drs M J R Hall, B R Pitkin, R P Lane and Mr J Lane, BK Iversen, $H$ Dahlberg, the staff of the Biomedical Library, UiTø, for help with technical aspects of this work, supplying larvae, photographic assistance, and to Rigmor Kearney for typing the manuscript.

1 James MT. The flies that cause myiasis in man. No 631 . Washington, DC: US Department of Agriculture, 1947:1-175.

2 Syrdalen P, Nitter T, Mehl R. Ophthalmomyiasis interna posterior: report of case caused by the reindeer warble fly posterior: report of case caused by the reinc

3 Syrdalen P, Stenkula S. Ophthalmomyiasis interna posterior. Graefes Arch Clin Exp Ophthalmol 1987;225:103-6.

4 Chirico J, Stenkula S, Eriksson B, et al. Oedemagena tarandi-a cause of human myiasis in Sweden. Läkartidningen 1987;84:2207-8.

5 Gjötterberg M, Ingemansson SO. Intraocular infestation by the reindeer warble fly larva: an unusual indication for acute vitrectomy. Br J Ophthalmol 1988;72:420-3.

6 Ward RA. Myiasis. In: Binford $\mathrm{CH}$, Connor DH, eds. Pathology of tropical and extraordinary diseases. Washington, DC: AFIP, 1976:626-30.

7 Baird JK, Baird CR, Sabrosky CW. North American cul cuter F. Myiasis in man and animals in the Old World. London: Butterworths, 1965:1-276.

9 Wood DM. Oestridae. In: McAlpine JF, ed. Manual of nearctic diptera. Vol 2, monograph 28. Ottawa: Departnearctic diptera. Vol 2, monograph 28. Otta

10 Bergmann AM. Über die Oestriden des Renntieres. Zeitschrift für Infektionskrankheiten, Haustiere 1919;20:
65-116, 179-201.

11 Cogley TP, Anderson JR, Weintraub J. Ultrastructure and function of the attachment organ of warble fly eggs. Int Insect Morphol Embryol 1981;10:7-18.

12 Hadwen S. Notes on the life history of Oedemagena tarandi L. and Cephenomyia trompe Modeer. J Parasitol 1927; 13:56-65.

13 Breyev KA, Breyeva ZF. Data on the biology of the reindeer warble fly Oedemagena tarandi. Conference on Rev Appl Entomol 1946;34:111.

14 Nelson WA, Weintraub J. Hypoderma lineatum (DeVill) (Diptera: Oestridae): Invasion of the bovine skin by newly hatched larvae. J Parasitol 1972;59:614-24.

15 Beesley WN. Observations on the biology of the ox warble-fly (Hypoderma: Diptera, Oestridae) III Dermolytic properties of larval extract. Ann Trop Med Parasitol 1969;63:157-9.

16 Aurstad K, Skeie AH. Proteolytic and lipolytic enzymes from larvae of Oedemagena tarandi (L.) Acta Vet Scand 1973;14:168-75.

17 Gomoyunova NP. Migration of larvae Oedemagena tarandi L. in the host's body. Izvestija Akademija nauk SSSR Sibirskoye otdelenie, Seria biologicheskich $i$ medizinskich nauk 1971;3:102-11.

18 Tashkinov NI. Migration of larvae of Oedemagena tarandi $\mathrm{L}$. at the artificial infection of deer. Parazitologiya $1976 ; 10: 50-60$.

19 Grunin KY. Hypodermatidae. In: Linder E, ed. Die Fliegen der palaearktischen Region. Stuttgart: 1965:64b; 1-154.

20 Rehbinder C. Observations of 1st instar larva of nostril fly Cephenemyia trompe in the eye of reindeer and their relation to keratitis in this animal. Acta Vet Scand 1970;11:338-9.

21 Mikkola K, Selvennoinen J, Hackman W. Ophthalmomyiasis caused by the elk throat botfly Cephenemyia ulrichii in man. Duodecim 1982;98:1022-5.

22 Nilssen AC, Haugerud RE. Bot flies (Oestridae) parasitizing Norwegian Cervidae. In: Abstract Proceedings. 19th International Union of Game Biologists Congress. Trondheim; IUGB, 1989:65

23 Steen M, Chirico J, Christensen D. Cephenemyia ulrichii Brauer 1862, in Swedish Moose. Acta Vet Scand 1988;29:265-6.

24 Anderson WB. Ophthalmomyiasis. Am J Ophthalmol 1935;18:699-705.

25 Rény A, Robert MH, Lepori JC, Condé B. Myiase intraoculaire à Hypodermatidae. Bull Mem Soc Fr Ophtalmol 1981;93:243-53.

26 Edwards KM, Meredith TA, Hagler WS, Healy GR. Ophthalmomyiasis interna causing visual loss. $\mathrm{Am} J$ Ophthalmol 1984;97:605-10.

27 Rapoza PA, Michels RG, Semeraro RJ, Green WR. Vitrectomy for excision of intraocular larva. Retina 1986;6: 99-104.

28 Natvig LR. Fliegenlarven als fakultative Parasiten bei Menschen und Tieren in Norwegen. In: Jordan K, Hering Menschen und Tieren in Norwegen. In: Jordan K, Hering EM, eds. Verhandlungen, VII Internationaler Kongress Für Entomologie. Weimar. Der Inte
Für Entomologie 1939;3:1641-55.

29 Lund-Larsen H. Hypodermalarver hos Mennesket. Norsk Vet Tidskr 1932;44:324-6.

30 Natvig LR. Om kubremsene og deres opptreden i Norge. Norsk Vet Tidsskr 1937;49:217-51.

31 Vasallo Matilla F. Descripción de la larva de Hypoderma lineata en caso de miasis humana. Rev Sanid Hig Pública 1973;47:613-24.

32 Rietschel G. Die Larvalentwicklung der Dasselfliege Oestromyia leporina. Pall Z Parasitenk 1975;47:283-97.

33 Custis PH, Pakalnis VA, Klintworth GK, Anderson WB, Machemer R. Posterior internal ophthalmomyiasis. Ophthalmology 1983;90:1583-90.

34 Newman PE, Beaver PC, Korzarsky PE, Waring GO. Fly larva adherent to corneal endothelium. Am J Ophthalmol 1986;102:211-6.

35 Hess C. Uber ein bisher nicht bekannte Ursache schwere eitringer Chorio-Retinitis mit Netzhautablösung. Archiv für Augenheilkunde 1913;74:227-9.

36 von Schmit zu Wellenburg H. Dipteren-Larve als Ursache eitriger Chorioretinitis mit Netzhaut-Ablösung. Centralblatt für praktische Augenheilkunde 1917;41:1-8.

37 Musial A. Larwa szklistki przyczyna ciezkiego zapalenia srodgalkowego (endophthalmitis larvosa). Klinika Oczna 1958;28:215-8.

38 Guadalupi U, Pamplione S. Miasi oculare interna posterior. Boll Oculist 1958;37:17-31.

39 Pulvertaft RJV. In: Duke-Elder S, ed. System of ophthalmology. Vol IX London: Kimpton, 1966:492.

40 molerna. Klinische Monatsblad für Augenheilkunde 1920;64:161-80. 41 Zeeman WPC. Ophthalmomyiasis subretinalis. Nederlands Tijdschrift voor Geneeskunde 1926;70:1192-7.

42 Archangelsky WN, Braunstein NE. Zur patologischen Anatomie der-Ophthalmomyiasis interna. Klinisch Monatsblad für Augenheilkunde 1931;87:340-50.

43 Ennema MC. Ophthalmomyiasis subretinalis. Arch Ophthalmol 1934;12:180-7.

44 Ahmed MJ, Miller A. Pulmonary coin lesion containing a horse bot, Gasterophilus. Am J Clin Pathol 1969;52: 414-9.

45 Kenney M, Eveland LK, Yermakov V, Kassouny DY. Two cases of enteric myiasis in man. Am J Clin Pathol 1976;66:786-91.

46 Jansen J. Hypodermatid larvae (Diptera: Hypodermatidae) from the musk ox Ovibus moschatus. Entomologische 
Berichten Amsterdam 1970;30:222-4.

47 Alendal $E$, Helle $O$. Helminth parasites of muskoxen Ovibus moschatus in Norway incl. Spitzbergen and in Sweden, with a synopsis of parasites reported from this host. Fauna norvegica Series $A$ 1983;4:41-52.

48 Nordkvist M. In: Skjenneberg S, Slagsvold L, eds. Reindriften og dens naturgrunnlag. Oslo: Scand University Books, 1968:1-332.

49 Nilssen AC, Gjershaug JO. Reindeer warble fly found in red deer. Rangifer 1988;8:35-7.

50 Haarr M. Ophthalmomyiasis interna posterior. Acto Ophthalmol Copenh 1945;23:135-41.

51 Gass JDM, Lewis RA. Subretinal tracks in ophthalmomyiasis. Trans Am Acad Ophthalmol Otolaryngol 1976;81:483-90.

52 Dixon JM, Winkler CS, Nelson JH. Ophthalmomyiasis interna caused by Cuterebra larva. Trans Am Ophthalmol Soc 1969;67:110-15.

53 Kersten RC, Shoukrey NM, Tabbara KF. Orbital myiasis. Ophthalmology 1986;93:1228-32.

54 Krümmel H, Brauns A. Myiasis des Auges. Agnew Zool 1956;43:129-90.

55 Purtscher A. Entfernung einer lebenden Larva von Hypoderma bovis aus dem Glaskörper. Zeitschrift für Augenheilkunde 1925;57:601-5.

56 Vesely L. Ksymptomatologii vnutornych oftalmomyaz. Cesk Oftalmol 1952;8:308-13.

57 Janukowiczowa H. Przypadek muszycy ciala szklistego (a case of vitreous body myiasis) Klin Oczna 1968;38: 579-82.

58 Rakusin W. Ocular myiasis interna caused by the sheep nasal bot fly. S Afr Med J 1970;44:1155-7.

59 Combe JC, Boiron M, Morel N, Duhamel C, Lecoq PJ. A propos d'un cas de myiase endoculaire postérieure. Bul prop ditmol Fr 1982;82:919-21.

60 Ducournau $D$, Bonnet $M$. Les ophtalmomyiasis internes postérieures. Bull Soc Ophtalmol Fr 1982;83:1529-30.

61 Massiot P, Quéré M-A, Baikoff G. Myiase intra-oculaire. Bull Soc Ophtalmol Fr 1983;83:417-8.

62 Chaine G, Bayen MC. Myiase intravitréenne. Bull Mèm Soc Fr Ophtalmol 1986;97:40-2.

63 Eickemeyer KA. Zur Ophthalmomyiasis interna. Klin $M b$ Augenhk 1957;130:95-102.

64 DeBoe MP. Dipterous larva passing from the optic nerve into the vitreous chamber. Arch Ophthalmol 1933;10: 824-5.
65 Hunt EW. Unusual case of ophthalmomyiasis interna posterior. Am J Ophthalmol 1970;70:978-80.

66 Lidstram AE Case of insect larva in the vitreous humour. Acta Ophthalmol 1926;4:72-5.

67 Byers B, Kimura SJ. Uveitis after death of a larva in the vitreous cavity. Am J Ophthalmol 1974;77:63-6.

68 Slusher MM, Holland WD, Weaver RG, Tyler ME. Ophthalmomyiasis interna posterior. Arch Ophthalmol 1979;97:885-7.

69 Ziemianski MC, Lee KY, Sabates FN. Ophthalmomyiasis interna. Arch Ophthalmol 1980;98:1588-9.

70 Mason G. Bilateral ophthalmomyiasis interna. Am J Ophthalmol 1981;91:65-70.

71 Haut J, Ullern M, Marre JM, Chatellier P, Chomette C, Hartmann C. Présentation d'un nouveau cas de parasitose endoculaire: myiase. Bull Mem Soc Ophtalmol Fr 1977; 77:929-30.

72 Fitzgerald CR, Rubin ML. Intraocular parasite destroyed by photocoagulation. Arch Ophthalmol 1974;91:162-4.

73 Dechant W, Pamba HO, Awan AM. Ein Fall von Ophthalmyiasis interna in Kenia. Klin Mbl Augenhk 1981;179: 368-9.

74 Forman AR, Cruess AF, Benson WE. Ophthalmomyiasis treated by argon laser photocoagulation. Retina 1984 4:163-5.

75 Subbotin PK, Murzin AA, Khizhniakova IN. Sluchai uspeshnogo lecheniia vnutriglaznogo oftal'momiaza (case of successful treatment of intraocular ophthalmomyiasis). Oftalmol-Zh 1986;ii: 125-6.

76 Potgeiter F, Scheuer JA. Ofthalmiiase met subretiale spore. $S$ Afr Med J 1979;55:957-8.

77 Vine AK, Schatz HS. Bilateral posterior internal ophthalmomyiasis. Ann Ophthalmol 1981;13:1041-3.

78 Steahly LP, Peterson CA. Ophthalmomyiasis. Ann Ophthalmol 1982;14:137-9.

79 Melding om reindrift 1987 . Reindriftsadministrasjonen Alta. Reindeer Management Administration 28.

80 Bjørklund I. For mye rein i Finnmark? (Too many reindeer in Finnmark?) Alta: Finnmark Dagblad, 1988: December 29,6 columns $1-5$.

81 Folstad I, Nilssen AC, Halvorsen O, Andersen J. "Why do male reindeer (Rangifer tarandus) have higher abundance of second and third instar larvae of Hypoderma tarandi than females?" Oikos 1989;55:87-92.

82 Haugerud RE. "Ivermectin del 1: Vidunderkur eller sovepute?" Reindriftsnytt 1988;22:23-5. 